\title{
Inchoativity, change of state, and telicity: Evidence from Spanish reflexive psychological verbs
}

\author{
Rafael Marín \\ CNRS/Université Lille 3 \\ rafael.marin@univ-lille3.fr
}

\author{
Louise McNally \\ Universitat Pompeu Fabra \\ louise.mcnally@upf.edu
}

\begin{abstract}
In this paper we argue that by making a careful distinction between the notions of inchoativity and telicity, we can gain new insight into how changes of state can be expressed in natural language. Our argument is based on an analysis of Spanish reflexive psychological verbs (SRPVs) such as aburrirse 'to be/become bored' and enfadarse 'to become angry'. We present diagnostics that clearly support the claim that while these verbs are inchoative, they are not telic, nor do they denote changes of state. Additional tests indicate that these verbs are not dynamic, either; however, we show that they lack dynamicity for different reasons: aburrirse verbs, because they are stative; enfadarse verbs, because they denote truly punctual eventualities. We present a formal semantic analysis using the event ontology proposed in Piñón (1997). This analysis allows us to capture very naturally the similarities and differences between the two subclasses of SRPVs, to characterize their inchoativity, and to distinguish it from telicity. In addition, it supports a view of the Vendlerian aspectual classes on which the achievement class describes truly punctual eventualities and excludes certain predicates commonly (if not universally) assumed to belong to this class, such as the so-called degree achievement verbs.
\end{abstract}

\section{Introduction}

Psychological verbs, which include e.g. English fear, frighten, disturb, worry, have generated interest largely because of their implications for the theory of argument structure (see, among many others, Belletti and Rizzi 1988; Dowty 1991; and more recently, Ackerman and Moore 2001 and references cited there). In this paper we address a different and equally challenging aspect of these predicates: their Aktionsart. Our goal, in addition to providing a novel analysis of certain psychological verbs in Spanish, is to shed light on the theory of Aktionsart in general, and the notions of inchoativity, change of state, and telicity in particular.

Although psychological predicates of the fear class are commonly assumed to denote states (Grimshaw 1990; Pustejovsky 1991; among others), there is much less consensus about the aspectual value to be assigned to those of the frighten type. For example, English frighten verbs have been argued to be (telic) achievement predicates (Van Voorst 1992) as well as accomplishment predicates (Tenny 1994; see e.g. Ryle 1949, Vendler 1967 and Dowty 1979 on the terms "achievement" and "accomplishment"). In contrast, Filip (1996) has argued that they are not telic, and both Pylkkänen (2000) and Arad (1998) have argued that at least some interpretations of some members of this class in Finnish (Pylkännen) and English and Romance (Arad) are stative.

One of the reasons for the existence of such a variety of analyses for the Aktionsart of psychological verbs has to do with the inherent syntactic complexity they manifest. As is well known, psychological verbs can participate in various alternations in different languages (see 
e.g. Belletti and Rizzi 1988). In Spanish, for example, many such verbs can appear in three syntactic configurations: accusative, $(1 \mathrm{a})$, dative, $(1 \mathrm{~b})^{1}$, and reflexive, $(1 \mathrm{c}) .^{2}$
(1)
a. Marta lo molesta.
Marta him.acc bothers
'Marta (actively) bothers/is bothering him.'

b. El humo le molesta.

the smoke him.dat bothers

'The smoke bothers him.'

\section{c. Josep se molesta. \\ Josep SE bothers \\ 'Josep gets bothered.'}

However, the discrepancy in the Aktionsarten associated with psychological verbs also suggests that part of the problem is a certain lack of consensus over how to characterize the very notions that are being used to describe these verbs - notions such as "inchoative predicate", "change of state predicate", or "achievement predicate".

The goal of this paper is to use an analysis of the reflexive variant in (1c) (hereafter, SRPVs, for Spanish reflexive psychological verbs), as a way of clarifying these and other notions that are central to the theory of Aktionsart. SRPVs are a particularly useful class for our theoretical purposes because they have been described using precisely the terms that interest us here. They are often classified as telic achievement predicates (De Miguel and Fernández Lagunilla 2000; McCready and Nishida 2008; see also Smith 1991 for the analogous class in French). An important motivation for the achievement analysis of SRPVs is arguably their reflexive morphology (the suffix -se in the infinitive, e.g. molestarse 'to get bothered'): This morphology has been associated with both inchoativity and change of state (Zagona 1996; De Miguel and Fernández Lagunilla 2000), and inchoativity, in particular, has often been associated with the achievement class (see e.g. Dowty 1979). Change of state predicates, for their part, are generally assumed to be telic or at least to admit a telic interpretation (e.g. Dowty 1979; Sanz and Laka 2002).

However, the results of our study confirm that inchoativity is logically distinct from telicity. They also demonstrate the need to distinguish predicates that truly refer to changes of state from those that simply entail that a change has taken place. In addition, they support the view defended in Mittwoch (1991) and Piñon (1997) that change of state predicates must be modeled differently from other verbs that are typically assigned to the achievement class of predicates in those aspectual typologies that assume such a class at all.

\footnotetext{
${ }^{1}$ Psychological verbs governing dative case are systematically stative (Grimshaw 1990, Ackerman \& Moore 2001). Those governing accusative can be associated with an agentive interpretation for the subject argument (Pustejovsky 1988, 1991), though the strength of the agentivity entailment varies among dialects; see e.g. Fontana (1991), Treviño (1992), Arad (1998), Cabré and Mateu (1998), and Parodi and Luján (2000) for more on these verbs. The glosses in the text reflect the judgments of the native speakers we have consulted whose judgments are stricter.

${ }^{2}$ A note on our conventions for glossing: For ease of reading, except where crucial for the discussion, we will gloss the Spanish examples with English equivalents rather than providing precise morphological decomposition. For example, the second person singular accusative weak pronoun te will be glossed as 'you' rather than as '2sg.acc'; a future tense form such as enfriaré will be glossed as '(I) will cool' rather than 'cool.1sg.fut.' Third person singular verbs in null subject sentences and third person singular dative pronouns are ambiguous between masculine and feminine; we will therefore gloss and translate these randomly using he/him or she/her; third person possessive pronouns are additionally underspecified for number, and will therefore be randomly glossed and translated as his, her, or their.
} 
Specifically, we argue that all SRPVs refer to the onset of the state they are associated with, without referring to the change that produces the state, in a way that we will describe in more detail in section 2 and subsequently formalize in section 4. In this sense, we argue, SRPVs are inchoative without being telic. However, we will also show that there are two aspectually distinct subclasses of SRPVs: one subclass, illustrated in (2a), also includes reference to the state in question - that is, we argue that inchoativity and stativity are not incompatible properties -, while another subclass, illustrated in (2b), does not include reference to the state but rather is strictly punctual according to the characterization of punctuality in Piñón (1997). We will call these subclasses the aburrirse and enfadarse classes, respectively, these verbs being representative members of the corresponding classes.
a. Marta se ha aburrido.
Marta SE has bored
'Marta has gotten bored.'
b. Josep se ha enfadado.
Josep SE has angered
'Josep has gotten angry.'

It is crucial to point out that in making this proposal for SRPVs, we do not imply that all verbs used to talk about change of state should be analyzed in the same way. Indeed, a key part of our argumentation will involve highlighting the contrasts between both subclasses of SRPVs, on the one hand, and the so-called degree achievement verbs such as enfriarse 'to cool' and related verbs such as cerrarse 'to close', on the other. ${ }^{3}$ These latter verbs are illustrated in (3):
a. La puerta se ha cerrado.
the door SE has closed
'The door has closed.'
b. La paella se ha enfriado. the paella SE has cooled
'The paella has cooled.'

As these verbs are also frequently characterized as "inchoative" or as "change of state" predicates, the differences we observe between them and SRPVs underscore the need to be more precise about what these terms mean. It will also become clear that even though degree achievement predicates are well known to manifest variable telicity (Dowty 1979, and e.g. Hay et al. 1999 for recent discussion), the sort of atelicity they are able to manifest is distinct from the atelicity we consistently find with SRPVs.

We proceed as follows. Section 2 presents some theoretical and terminological background to clarify the discussion that follows. In section 3 we present a set of diagnostics for the aspectual properties of SRPVs. We present a formal analysis for the two classes of SRPVs in section 4, and provide a brief discussion in section 5 of other analyses of se predicates in Spanish. Section 6 offers our conclusions.

\footnotetext{
${ }^{3}$ Although cerrarse does not fall into the classic list of degree achievement verbs, it shares important properties with these verbs. For ease of exposition, throughout the paper we will use terms such as "enfriarse-type verbs" or "the enfriarse class" to refer to the union of the degree achievements plus related verbs such as cerrarse and abrirse 'to open'.
} 


\section{Theoretical and terminological background}

Verbs are typically classified aspectually into three or four large groups (such as Vendler's 1967 state, activity, accomplishment and achievement classes), according to their behavior on a set of diagnostics. As the literature on these diagnostics and the classes themselves is large we cannot do justice to it here (recent volumes include Verkuyl, et al. 2005, Dölling, et al. 2007, and Rothstein 2008b, and see Erteschik-Shir and Rapoport 2005 and Kempchinsky and Slabakova 2005 for more syntactically-oriented discussion). Rather, in this section we focus very briefly on four of the individual properties that have been claimed to characterize the different aspectual classes - inchoativity, change of state, telicity, and dynamicity - and how these properties can present problems for aspectual classification, particularly in the cases that interest us in this paper. Unless we have something relatively precise to say about these properties, claims such as "Verb V is an achievement predicate" will be confusing at best and meaningless at worst; correspondingly, what is important to us is not so much whether one decides to use terms such as "achievement" in reference to one particular cluster of properties or another; rather, what matters is identifying the specific cluster of properties that appropriately classifies a given group of verbs in opposition to other groups of verbs that behave differently.

\subsection{Inchoativity and change of state}

Dowty's (1979) treatment of the Vendlerian classes exemplifies exactly the sort of precise definition we need, and his characterization of the achievement class in terms of a BECOME operator is a good place to start our discussion about inchoativity, change of state, and telicity. Dowty (1979:141) defines BECOME as in (4):

(4) $[\mathrm{BECOME} \varphi]$ is true at $I$ iff (1) there is an interval $J$ containing the initial bound of $I$ such that $\neg \varphi$ is true at $\mathrm{J},(2)$ there is an interval $K$ containing the final bound of $I$ such that $\varphi$ is true at $K$, and (3) there is no non-empty interval $I^{\prime}$ such that $I^{\prime} \subset I$ and conditions (1) and (2) hold for $I^{\prime}$ as well as $I$.

Though the definition is rather technical, the idea is simple: [BECOME $\varphi$ ] is true at the smallest interval which consists of an interval in which $\varphi$ is not true immediately followed by an interval in which $\varphi$ is true. With this operator, the semantics of sentences such as (3b) can be represented as in (5), where $\mathbf{p}$ represents la paella, $d_{i}$ is the degree to which the paella cools (see Hay et al. 1999), and we ignore tense:

\section{$\mathrm{BECOME} \operatorname{cool}\left(\mathbf{p}, d_{i}\right)$}

It is clear in what sense predicates analyzed in terms of BECOME can be considered inchoative: They include reference to the initial interval at which a proposition $\varphi$ is true. However, note that the definition also includes reference to the final interval at which $\neg \varphi$ is true. Thus, the proposition in (5) effectively picks out the transition from $\neg \varphi$ to $\varphi$, and we can say that BECOME also clearly models change, in this case, change of state.

Dowty's BECOME (and event semantics versions of it, such as the definition in von Stechow 1996) makes the intimate connection between inchoativity and change explicit. But it is also logically possible to imagine a semantics specifically for inchoativity which excludes reference to change. Imagine that a predicate is lexically specified to refer to the true initial interval of a state, but not to any interval prior to the onset of that state. If the predicate entails reference to this initial interval, it will have to be the case that prior to that 
interval, the state did not hold. From this fact it will be possible to infer that a change has taken place immediately prior to the onset of the state being referred to. Thus, though such a predicate would qualify as inchoative in the same sense as BECOME, it would not qualify as a change of state predicate in the same sense.

An example of an inchoatively interpreted predicate (presumably via pragmatic inference) that does not refer to a change of state appears in the English sentence in (6), in which the stative predicate to be upset is used even though the most natural interpretation of the sentence (though not the only one) is one on which Marta becomes upset upon being told that she cannot go away for the weekend.

Marta was upset when I told her she couldn't go away for the weekend.

Of course to be upset does not force reference to the initial interval of being upset; in (6), the fact that prohibitions or impossibilities often happen to cause upset simply makes it likely that the onset of the state coincides with the hearing of the news. But the fact that this stative sentence seems to convey change of state leads naturally to the question of whether some languages might actually require lexically that some predicates refer to the onset of a state without referring to the change producing that state. We think the answer to this question is positive, and that SRPVs exemplify precisely this kind of option, as we will argue in section 3 and made explicit in section 4.

\subsection{Telicity}

Telicity is arguably more difficult to define formally than either inchoativity or change of state, and the notion has been the subject of a substantial literature (see Krifka 1989, Parsons 1990, Pustejovsky 1995, Hay et al. 1999, Borik 2006, Rothstein 2008a, Kennedy and Levin 2008, and Piñón 2008, for just some examples of different approaches). Two recurring intuitions appear in the attempts to characterize telicity: on the one hand, the idea that telicity, whether applied to events themselves or to predicates describing such events, involves some sort of "natural" endpoint; and, on the other, the idea that telic predicates lack homogeneous reference - roughly speaking, a telic predicate that holds truthfully of an event should not hold truthfully of any nonfinal proper part of that event.

To what extent and how these intuitions can be captured in a formal definition of telicity is intimately connected with how the so-called achievement predicates are analyzed, and with how putative candidates for the achievement class behave on reliable tests for telicity. The achievement predicates are crucial because of the debate over whether or not they are truly instantaneous, as opposed to simply of very short duration. Consider, for example, a verb such as arrive, which passes the more reliable tests for telicity (see e.g. Dowty 1979) and is generally classified as an achievement predicate. If we characterize its semantics in terms of BECOME (see (4)), we can in principle capture its telicity either with a definition that appeals to a notion of natural endpoint or one which refers to (lack of) homogeneous reference: the temporal extension of the event is small, but sufficient to differentiate nontrivial subevents which might not be homogeneous, and one of which might be identifiable as ending the event naturally. However, if we follow e.g. Piñon 1997 in considering achievements to be truly instantaneous, we will not be able to appeal to BECOME (whose definition can only characterize events of more than instantaneous length); some alternative will be necessary.

Though we will present Piñón's semantics in greater detail below, we introduce the general idea here to make clear how its basic premises can lead to a rather different picture of inchoativity, change, and telicity. Piñón's semantics distinguishes between two 
fundamentally different types of eventualities: on the one hand, those with some duration, however small (which he calls happenings); and, on the other, boundary happenings, which, as their name suggests, are the initial or final boundaries of some happening. Boundary happenings are absolutely instantaneous. Piñón argues that predicates such as begin or arrive denote boundary happenings, whereas a change of state predicate like cool does not.

As mentioned above, we will argue that some SRPVs denote instantaneous eventualities - that is, boundary happenings - but are not telic. However, we will not want to claim that all boundary happenings are atelic. And of course it will have to be possible for ordinary happenings to be telic as well. What kind of definition of telicity can we adopt? The postulation of truly instantaneous eventualities seems problematic for a definition in terms of homogeneous reference. Whether such eventualities can have proper parts or not seems to be more a matter of definition than intuition, and therefore we might expect predicates that denote boundary happenings to always be telic or, alternatively, never be telic. ${ }^{4}$ However, this expectation is borne out by the Spanish data. A definition in terms of a natural endpoint is therefore our only alternative. Fortunately, such an alternative can be made to work.

Piñón argues that a key part of characterizing the semantics of those predicates that denote boundary happenings involves making explicit what (ordinary) happenings they denote the boundaries of, and whether the boundary in question is an initial or final boundary (or simultaneously the final boundary of one happening and the initial boundary of another). If this is so, we might opt to define telic predicates as just those whose denotation necessarily includes reference to a final boundary happening of some eventuality. On such a view, an otherwise diverse group of predicates would count as telic, including those that denote happenings plus their final boundary, those that denote just a final boundary of some happening (without denoting the happening itself), those that denote both the final interval of some happening and the initial interval of another, and those that denote just that boundary which is defined simultaneously as the end of one happening and the beginning of another. In contrast, a predicate which is defined as denoting just the initial boundary happening of an eventuality, or one which lacks reference to any boundary happening at all, would not be telic. Though we will not explore the complex issue of telicity in detail in this paper, it should be clear that such a definition can in principle serve as the basis for distinguishing atelic SRPVs from telic achievement predicates such as arrive.

\subsection{Dynamicity}

Finally, as dynamicity will play a role in our empirical discussion, we provide some brief reflections on the notion. Typically, dynamicity is used to distinguish stative predicates from all other aspectual classes. However, whether this is actually how dynamicity should divide up the inventory of eventuality types depends on exactly how those types are modeled. In order for an eventuality to be dynamic, it must have some characteristic - change or motion, for example - that prevents it from being absolutely homogeneous. ${ }^{5}$ But note that this characterization of dynamicity presupposes that dynamic eventualities must have some minimal duration: otherwise, it would be impossible to talk about any change or motion. ${ }^{6} \mathrm{~A}$

\footnotetext{
${ }^{4}$ Piñón in fact defines boundary happenings as homogeneous. His system allows for building nonatomic boundary happenings out of atomic ones: among other possibilities, it licenses a nonatomic boundary happening which is the sum of the right boundary of one happening and the left boundary of another - for instance, the end of an activity and the beginning of a state. However, despite being nonatomic, such objects are boundary happenings nonetheless and as such are instantaneous. In other words, there is no way in his system to put a set of boundary happenings together to make an ordinary happening with some temporal duration.

${ }^{5}$ Homogeneity is also used to characterize activity predicates, but the level of granularity at which such predicates have homogeneous reference will never be as fine as in the case of stative predicates.

${ }^{6}$ See e.g. Dowty (1979) for relevant discussion in connection with the semantics of the verbs sit, stand, and lie.
} 
crucial question is therefore whether the inventory of eventuality types includes any that are truly punctual, and on this point, analyses differ. Here it is again crucial to consider the achievement predicates. If we adopt Piñón's semantics for the achievement class, we predict that they should pattern with stative predicates in failing tests for dynamicity. On the other hand, if we were to adopt any analysis of the same predicates on which the eventualities they describe are not truly instantaneous (such as Dowty's), those predicates should not fail tests for dynamicity. Dynamicity tests therefore constitute an interesting source of evidence for how the predicates typically assigned to the achievement class should be modeled.

With this background established, we now turn to the relevant empirical properties of SRPVs.

\section{Aspectual properties of SRPVs}

As mentioned above, and as will become increasingly clear as we proceed, SRPVs fall into two well-defined subclasses, "nonpunctual" and "punctual", and which we will refer to as the aburrirse and enfadarse classes, respectively. ${ }^{7}$ A representative list of each class appears in (7): ${ }^{8}$

(7) a. Nonpunctual (aburrirse class): agobiarse 'to get/feel overwhelmed,' angustiarse 'to get/be distressed,' avergonzarse 'to get/feel ashamed,' confundirse 'to get/be confused,' distraerse 'to get/be distracted,' entretenerse 'to get/be entertained,' interesarse 'to get/be interested in,' molestarse 'to get/be bothered,' obsesionarse 'to get/be obsessed,' preocuparse 'to get/be worried'

b. Punctual (enfadarse class): asombrarse 'to be amazed,' asustarse 'to get frightened,' cabrearse 'to get really mad,' enfurecerse 'to get furious,' enojarse 'to get annoyed,' excitarse 'to get excited,' indignarse 'to become indignant,' mosquearse 'to get irritated,' ofenderse 'to get offended,' sorprenderse 'to be surprised'

Though it is not immediately obvious by looking at the verbs in isolation what the members of each class have in common (other than that, statistically speaking, people might tend to get bored, interested, obsessed, etc., gradually, and to get angry, furious, amazed, etc., very quickly), a number of diagnostics support the classification in (7). Several of these will be discussed below; to give just one initial example here, the classes contrast in their entailments in the progressive. When aburrirse verbs appear in the progressive, they entail that the referent of their subject is in the state described, as the gloss in (8) indicates.

$$
\begin{aligned}
& \text { Juan se está aburriendo. } \\
& \text { Juan SE is boring } \\
& \text { 'Juan is (already) bored.' }
\end{aligned}
$$

\footnotetext{
${ }^{7}$ Though the tests we provide below work consistently for the members within a given class, for simplicity we will tend to use aburrirse and enfadarse themselves to exemplify (and hope that we will neither bore nor anger the reader in so doing).

${ }^{8}$ Some verbs of physical change of state, e.g. marearse 'to get dizzy', hartarse 'to get satiated/fed up', seem to show a similar bifurcation, though we must leave an analysis of this class, along with a deeper explanation as to why each verb in (7) falls into the class it does, for future research.
} 
In contrast, when enfadarse verbs appear in the progressive form, they entail that the subject of the predication is not yet in the state described by the verb, as the gloss in (9) indicates:

\author{
El perro se está asustando. \\ the dog $\mathrm{SE}$ is frightening \\ 'The dog is getting (but is not yet) frightened.'
}

The fact that enfadarse verbs appear in the progressive might initially seem to conflict with the claim that they are "punctual". However, as we will show in section 3.7, sentences like (9) are instances of what Kearns (2003) calls the "preliminary circumstance" interpretation of the progressive (see also Piñón 1997 for similar observations), an interpretation that is characteristic of achievement predicates such as arrive or win.

In the remainder of this section, we contrast these two subclasses with other relevant classes of Spanish verbs on a series of diagnostics that we take to indicate very specific lexical aspectual properties: telicity, durativity, dynamicity, and inchoativity. The results will show that the two subclasses coincide in inchoativity and in lack of telicity and dynamicity, though (as might be expected given the initial characterization of the subclasses), they contrast in durativity.

\title{
3.1. en/durante ('in/for') adverbials
}

It is a well established generalization that only telically interpreted predicates can be modified by adverbials of the type in $x$ time (see e.g. Dowty 1979). In contrast, durative (for $x$ time) adverbials are not compatible with telic predicates except on an iterative reading or on a reading which does not entail that the event described by the predicate has finished. We observe the same behavior in Spanish for en 'in' and durante 'during (i.e. 'for')' adverbials:

a. Escribió su tesis *durante/en nueve meses. wrote her thesis during/in nine months

[telic predicate] 'She wrote her thesis in nine months.'

b. Paseó durante/*en una hora.

[atelic predicate] strolled during/in an hour 'He strolled for an hour.'

$\begin{array}{llll}\text { c. Admiró a su } & \text { jefe durante/*en } & \text { un año. } & \text { [atelic predicate] } \\ \text { admired to her } & \text { jefe during/in } & \text { a year } & \end{array}$ 'She admired her boss for a year.'

Like atelic predicates, all SRPVs resist modification by en adverbials. With durante adverbials we find the first sign of a contrast between the two subclasses of verbs: while aburrirse verbs are perfectly acceptable with such adverbials on a noniterative reading, further underscoring their atelicity, enfadarse verbs allow durante modification only with an iterative reading.

\footnotetext{
${ }^{9}$ Although speakers do not find sentences like (10a) with durante very acceptable, for some speakers they sound better if the verb is in the imperfect rather than the preterite form. What is crucial is the contrast with the atelic verbs in (10b-c), which are perfectly acceptable with durante even though they appear in the preterite.
} 
a. Se $\{$ aburrió/divirtió $\}$ durante/*en toda la tarde.

SE $\{$ bored/amused $\}$ during/in all the afternoon

'He was bored/amused (continuously) the whole afternoon.'

b. Se \{asustó/enfadó\} durante/*en toda la tarde.

SE \{frightened/angered\} during/in all the afternoon

'She got frightened/angry (repeatedly) the whole afternoon.'

This contrast is due to the fact that durative adverbials are sensitive not just to the telicity of a predicate, but also to its durativity. Obviously, a verb which describes a truly instantaneous eventuality will not accept modification by an adverbial that entails that the eventuality lasts for some nontrivial amount of time, unless that verb can be interpreted iteratively and the adverbial can describe the total duration of the iterated eventualities. Thus, the contrast in behavior with durante adverbials indicates that while aburrirse predicates are durative, enfadarse predicates are not.

SRPVs contrast strikingly on this diagnostic with change of state verbs such as cerrarse or enfriarse, which do accept modification by en:

a. Las puertas se abrieron en un instante.

the doors SE opened in an instant

'The doors opened in an instant.'

b. El agua se evaporó en cinco minutos.

the water SE evaporated in five minutes

'The water evaporated in five minutes.'

The acceptability of the sentences in (12) indicates that these verbs have a telic interpretation. ${ }^{10}$

\subsection{Acabar/terminar ('finish')}

A second piece of evidence for the atelicity of SRPVs is their incompatibility with predicates such as acabar or terminar 'finish', which lexically require that their infinitival complement describe an action that can be completed (Dowty 1979): ${ }^{11}$

a. *Ha terminado de \{aburrirse/preocuparse\}. has finished of bore-SE/worry-SE

'She has finished being bored/worried.'

b. *Ha terminado de asustarse/enfadarse.

has finished of frighten-SE/anger-SE

'He has finished getting frightened/angry.'

The examples below show that only telic predicates can be complements of acabar or terminar; atelic predicates cannot be:

\footnotetext{
${ }^{10}$ Of course, degree achievement verbs are also acceptable with durante adverbials if interpreted atelically.

${ }^{11}$ In fact, acabar/terminar, like durante adverbials, also select for durative predicates, so the impossibility for punctual SRPVs to combine with acabar/terminar could be due to their punctuality as well.
} 
(14) a. Ha acabado de pintar la baranda.

[potentially telic predicate]

has finished of paint the railing

'She has finished painting the railing.'

b. *Ha terminado de acariciar al perro.

[atelic predicate] has finished of pet the dog

'He has finished petting the dog.'

c. *Ha acabado de preferir las acelgas.

has finished of prefer the chard

[atelic predicate]

'She has finished preferring chard.'

In contrast, enfriarse-type verbs are acceptable in these contexts:

a. El agua ha acabado de evaporarse.

the water has finished of evaporate-SE

'The water has finished evaporating.'

b. La puerta ha terminado de abrirse.

the door has finished of open-SE

'The door has finished opening.'

Once again, then, we see a contrast between SRPVs and other change of state predicates that places the former clearly in the atelic class, in contrast to the latter.

\subsection{Incompatibility with una vez absolutes}

A third and very strong piece of evidence for the atelicity of SRPVs come from their failure to appear in absolute constructions of the form [una vez lit. 'one time' + past participle + NP], discussed in detail in Hernanz (1991) and Hernanz and Suñer (1999). These absolutes do not have an exact translation into English, but most can be paraphrased with a clause introduced by once in the sense of "posterior to," as exemplified in (16):

(16) Una vez terminadas las obras, podremos volver a casa. one time finished the renovations, will be able return to home 'Once the renovations have finished, we will be able to return home.'

As the translation indicates, the una vez absolute functions as a kind of temporal modifier which should not be confused with other kinds of absolutes in Spanish. Both absolutes with una vez but no NP, as in (17a), and absolutes of the form [past participle + NP] but without una vez, (17b), exist in Spanish, but both have rather different properties from the construction which interests us here - including differences in their compatibility with participles based on SRPVs.

(17) a. Una vez restaurado, el edificio se destinará a pisos de protección oficial. one time restored the building SE will use to apartments of protection official 'Once restored, the building will be used for rent-controlled apartments.' 
b. Arreglado el coche, pudimos continuar el viaje. repaired the car, could. 1 pl continue the trip

'Once the car was repaired, we could continue the trip.'

Since the absolutes in (17) are not selective in the participles they permit, what we have to say below does not apply to them, and they will not form part of our argumentation here (see Marín 1996 and Pérez Jiménez 2007 for more on the different kinds of absolutes in Spanish).

It is a striking fact that una vez absolutes with the structure in (16) permit past participles of only telic verbs to appear in them. ${ }^{12}$ These participles can be derived from any kind of telic predicate: (18a-b) contain past participles of prototypical achievement predicates; (18c-d), participles based on potential accomplishment predicates; and (18e), a participle based on an enfriarse-type verb: ${ }^{13}$

(18) a. Una vez descubierto el traidor, la película perdió interés. one time discovered the traitor, the film lost interest 'Once the traitor had been discovered, the film lost interest.'

b. Una vez alcanzado el acuífero, hay que verificar sus características. one time reached the aquifer, has that verify its characteristics 'Once the aquifer has been reached, it is necessary to verify its characteristics.'

c. Una vez traducido el texto, el sistema lo convierte en palabras. one time translated the text, the system it converts in words 'Once the text has been translated, the system converts it to words.'

d. Una vez leídas todas las preguntas, pueden empezar a contestar. one time read all the questions, can start to answer 'Once all the questions have been read, you can start to answer.'

e. Una vez evaporada el agua, se extrae la sal. one time evaporated the water, SE extract the salt 'Once the water has evaporated, the salt is extracted.'

In contrast, participles derived from atelic verbs are excluded, whether these verbs are dynamic (including so-called semelfactives), as in (19), or stative (including those describing normally transitory states), as in (20):

\footnotetext{
${ }^{12}$ An anonymous reviewer suggests that rather than prohibiting telic predicates, the una vez + past participle + NP construction might prohibit non-result-state predicates. However, this cannot be the case: participles derived from verbs which are telic but lack result states applicable to their overt arguments are acceptable in the construction:
}

(i) Una vez cruzado el río, estuvimos a salvo. one time crossed the river were. $1 \mathrm{pl}$ safe 'Once the river was crossed, we were safe.'

$$
\begin{gathered}
\text { *El río está cruzado. } \\
\text { the river is crossed }
\end{gathered}
$$

See Marín (2004) for additional discussion.

${ }^{13}$ The totally nonagentive nature of the interpretation of this sentence indicates that the participle is derived from the intransitive verb evaporarse and not the transitive verb evaporar; no reflexive morphology appears simply because reflexive morphology never appears on past participles in Spanish. 
a. *Una vez sonado el teléfono, nos sentimos aliviados. one time rang the phone, we felt better. Intended: 'Once the phone rang, we felt better.'

b. *Una vez conducido el coche, se había acabado la prueba. one time driven the car, SE has finished the test Intended: 'Once the car had been driven, the test was over.'

(20) a. *Una vez sabidos los hechos, el jurado se puso a deliberar. one time known the facts, the jury SE put to deliberate Intended: 'Once the facts were known, the jury went to deliberate.'

b. *Una vez debido el favor, estarás en una situación muy incómoda. one time owed the favor, will be in a situation very uncomfortable.' Intended: 'Once the favor is owed, you will be in a very uncomfortable situation.'

Crucially, participles based on SRPVs are systematically unacceptable in una vez absolutes:

a. *Una vez divertido el público, dejarán de quejarse así. one time amused the audience, will stop of complain-SE like that Intended: 'Once the audience is amused, they'll stop complaining like that.'

b. *Una vez preocupados tus padres por tu situación, te ayudarán. one time worried your parents about your situation, you will help Intended: 'Once your parents are worried about your situation, they will help you.'

c. *Una vez enfadado el director, los actores trabajaron más. one time angry the director, the actors worked more Intended: 'Once the director was angry, the actors worked more.'

d. *Una vez asustados los niños, sus padres los sacaron de la atracción. one time frightened the children, their parents them took off of the ride Intended: 'Once the children were frightened, their parents took them off the ride.'

We consider this a strong argument for the atelicity of all SRPVs, as there is nothing pragmatically wrong with the situations that the sentences in (21) are trying to describe. It is worth emphasizing, moreover, the fact that una vez absolutes do not require participles based on durative predicates, as examples (18a-b) show, so the oddness of enfadarse verbs in these constructions $(21 \mathrm{c}-\mathrm{d})$ can only be due to their atelicity.

\subsection{Lentamente ('slowly')}

Having presented three diagnostics related to telicity, we now turn to diagnostics for nondynamicity of SRPVs.

The first (non)dynamicity test comes from their incompatibility with adverbs like lentamente 'slowly', which, on their manner interpretation, can only apply to predicates that denote eventualities which involve some sort of development over time (De Miguel 1999). Dynamic predicates, including verbs of the enfriarse class, can be modified by such adverbs: 
(22) a. Juan camina lentamente.

Juan walks slowly

'Juan walks slowly.'

b. Escribió una carta lentamente.

wrote a letter slowly

'S/he wrote a letter slowly.'

c. El agua se enfrió / se evaporó lentamente.

the water SE cooled / SE evaporated slowly

'The water cooled / evaporated slowly.'

In contrast, stative predicates cannot be modified by lentamente.
a. *Juan detesta las acelgas
lentamente.
Juan hates the Swiss chard
slowly
b. *Juan admira a su hermano lentamente. Juan admires to his brother slowly
c. *Maria estaba enferma lentamente.
Maria was sick slowly

Similarly, when lentamente modifies a predicate that denotes an arguably instantaneous event, such as empezar 'begin' or llegar 'arrive', if the adverb is acceptable at all, it does not describe the speed with which the event actually takes place but rather the speed with which some ancillary event takes place - for example, in the case of (24a), the speed at which the rain falls, but not the speed at which the beginning takes place; and in the case of (24b), the speed at which the airplane approaches the airport, but not the speed at which it can be literally said to arrive (see Piñón 1997, who makes this point for English). ${ }^{14}$
a. Empezó a llover lentamente.
began to rain slowly
'It began to rain slowly.'
the airplane arrived slowly
'The airplance arrived slowly.'
b. El avión llegó lentamente.

Crucially, SRPVs cannot be modified by lentamente on a reading which describes the speed at which the psychological state progresses, as shown in (25):

\footnotetext{
${ }^{14}$ When the subject of empezar 'arrive' denotes an individual which can be said to arrive in progressive parts, then the collective arrival of those parts can be described as slow, as in (i):

(i) Los invitados llegaron lentamente. the guests arrived slowly

'The guests arrived slowly.'

However, note that (i) does not entail that any given guest arrived slowly. This lack of entailment is exactly as we predict if lentamente cannot describe atomic acts of arrival, as we suggest in the text.
} 

a. *Juan se aburre / se obsesiona / se preocupa lentamente. Juan SE bores / SE obsesses / SE worry slowly

b. *Juan se asusta / se enfada / se sorprende lentamente. Juan SE frightens / SE angries / SE surprises slowly

We therefore conclude that SRPVs denote eventualities that lack any sort of internal development; in other words, they are not dynamic. However, the differences we have seen between the two subclasses in their behavior with durante adverbials and the progressive, and the differences we will see below in their interpretation in the simple present tense, support our claim that aburrirse verbs are nondynamic because they are stative, while enfadarse verbs are because they are punctual.

\subsection{Incompatibility with parar ('stop')}

A second test for the nondynamicity of SRPVs involves the verb parar 'stop', one of several verbs of stopping in Spanish. Nondynamic verbs in Spanish are impossible in the complement to parar (De Miguel 1999): contrast the acceptable examples involving dynamic verbs in (26) with the unacceptable examples involving stative verbs in (27):

(26) a. Ha parado de pintar la baranda.

has stopped of paint the railing

'He has stopped painting the railing.'

b. ¡Para ya de llorar!

stop already of cry

'Stop crying already!'

c. Ha parado de llover.

has stopped of rain

'It's stopped raining.'

d. Mira, el globo ha parado de subir.

look, the balloon has stopped of rise

'Look, the balloon has stopped rising.'

(27)
a. *Ha parado de admirar a su
hermano. has stopped of admire to his brother
'He has stopped admiring his brother.'
b. *Ha parado de ser mi amigo.
has stopped of be my friend
'She has stopped being my friend.'
c. *Ha parado de estar enfermo.
has stopped of be sick
'He has stopped being sick.'

Parar is incompatible with stative verbs not because states are unstoppable - obviously, states can cease - but rather because it appears to be a lexical peculiarity of parar that it 
specifically entails the cessation of a dynamic eventuality. The condition imposed on the complement of parar by this entailment conflicts with the lack of dynamicity fundamentally characteristic of stative verbs. ${ }^{15}$ The cessation of a state must be expressed using a different verb in Spanish, principally dejar 'stop' (De Miguel 1999).
a. Ha dejado de admirar a su
hermano. has stopped of admire to his brother
'He has stopped admiring his brother.'

b. Ha dejado de ser mi amigo.

has stopped of be my friend

'She has stopped being my friend.'

c. Ha dejado de estar enfermo.

has stopped of be sick

'He has stopped being sick.'

Crucially, unlike enfriarse-type verbs, shown in (29), SRPVs are also incompatible with parar, though they, like stative verbs are compatible with dejar, as shown in (30):

a. El agua ha parado de evaporarse.

the water has stopped of evaporate

'The water has stopped evaporating.'

b. La puerta ha parado de abrirse.

the door has stopped of open

'The door has stopped opening.'

(30) a. Ha * parado / dejado de \{aburrirse/agobiarse\}.

has stopped of bore-SE/overwhelm-SE

'She has stopped being bored/being overwhelmed.'

b. Ha *parado / dejado de \{enfadarse/asustarse\}.

has stopped of anger-SE/frighten-SE

'He has stopped getting angry/frightened.'

The incompatibility of aburrirse verbs with parar clearly indicates that they are stative, since we have already seen evidence that such verbs are durative. In the case of the enfadarse class, the incompatibility could also be due to the punctuality of the verbs in question. Interestingly, other punctual verbs, such as llegar 'arrive', are acceptable as the complement to parar on an iterative reading:

(31) Por fin ha parado de llegar tanto correo comercial. at last has stopped of arrive so much mail commercial 'At last so much junk mail has stopped arriving.'

\footnotetext{
${ }^{15}$ Note that the restriction on parar does not involve agentivity/control; an agentless predicate such as llover 'to rain' combines felicitously with parar, as seen in (26c).
} 
In contrast, even on an iterative reading with enfadarse verbs, there is a strong preference for the verb dejar:

(32) A ver si dejas ya de \{enfadarte/asustarte\}. to see if stop already of anger-SE/frighten-SE

'Let's see if you finally stop getting angry/frightened.'

Though we do not have an explanation for this contrast, anticipating our analysis in section 4, it might eventually be accounted for under the hypothesis that llegar denotes the endpoint of a dynamic eventuality, while enfadarse denotes the onset of a state.

\subsection{Interpretation of the present tense}

We now turn to an argument specifically for the stativity of aburrirse verbs, namely their interpretation in the present tense. The enfadarse verbs do not pass this test, indicating that they are not stative.

As in English, dynamic predicates in Spanish, including verbs like enfriarse and those in (33a-c), have only a habitual or otherwise special reading in the simple present (like that found in the historical present or immediate futurate use), whereas stative predicates such as that in (33d) can and typically do have a nonhabitual interpretation:

a. $\quad \mathrm{Su}$ padre corta el césped.

their father cuts the grass

'Their father (habitually) cuts the grass.'

b. $\quad \mathrm{Su}$ hermano conduce el camión.

their brother drives the truck

'Their brother (habitually) drives the truck.'

c. El agua se evapora.

the water SE evaporates

'The water (habitually) evaporates.'/ 'Water (generically) evaporates.'

d. Le gustan los hombres con barba.

Her like the men with beards

'She likes men with beards.'

As (34) shows, the aburrirse class of SRPVs behaves exactly like other stative predicates in this respect.

(34) a. Se preocupa por el futuro de sus hijos.

SE worry for the future of her children

'She is worried (now) about the future of her children.'

b. Con su hermana pequeña se aburre.

with his little sister SE bores

'With his little sister he is bored (now).'

In contrast, enfadarse verbs do not: They only allow a generic or habitual reading in the simple present, as in (35). 
(35) Se asombra/asusta con los fuegos artificiales.

SE amaze/frighten with the fires artificial

'He is (generally) amazed/frightened by fireworks.'

Not: 'He is amazed/frightened (now) by the fireworks.'

This is a clear argument for not taking the enfadarse class to be stative, even if they do not otherwise manifest dynamicity.

\subsection{The progressive}

Further support for the view of SRPVs that we are developing can be found in their interpretation in the progressive, which we briefly introduced at the beginning of this section. The interpretation a predicate has in the progressive can be used as a test for the durativity and telicity of the eventuality the predicate describes. The basic intuition (found in e.g. Bennett and Partee 1972, Taylor 1977, and Dowty 1979, among others) is that the progressive imposes the condition that the predicate it combines with must describe a situation with a certain temporal extension and homogeneity. ${ }^{16}$ Two predictions are thus made. First, any predicate describing situations with some duration should be acceptable in the progressive, ${ }^{17}$ while those referring to truly punctual events should not be. Although the acceptability of many achievement predicates in the progressive might lead one to question the correctness of this prediction, we will follow argumentation from Kearns (2003) and take such putative counterexamples to be only apparent. The second prediction is that telic and atelic predicates should yield different inference patterns in the ordinary (i.e., not the preliminary circumstance) progressive: an atelic predicate $\mathrm{V}$ should license the inference from the progressive to the perfect ( $X$ is Ving entails $X$ has $V e d$ ), while a telic predicate should not ( $X$ is Ving does not entail $X$ has Ved).

Kearns (2003) provides three tests which distinguish this progressive from the typical progressive that carries the subinterval condition. Kearns notes that the preliminary circumstance progressive is compatible with the event described by the verb beginning in the future, while the typical progressive is not. (36) illustrates this contrast: according to this test, enfadarse verbs, as in (36a), manifest the preliminary circumstance progressive, while aburrirse verbs, as in (36b), do not. (36c) shows that verbs such as enfriarse also do not manifest the preliminary circumstance progressive, indicating that they, unlike enfadarse verbs, describe eventualities with some duration.

a. Se está enfadando y se va a enfadar

SE is angering and SE go to anger

'She is getting angry, and she is going to get angry.'

\footnotetext{
${ }^{16}$ Note that we exclude from this discussion futurate uses of the progressive as in They are arriving tomorrow.

17 According to this intuition, in principle stative predicates should occur in the progressive; however the contrary is often claimed to be the case, based on the oddness of examples such as (i):
}

(i)

??Juana is knowing French.

These claims notwithstanding, there is ample evidence that stative predicates can appear in the progressive under certain conditions; see Gavis (1998) for an exhaustive discussion and examples. Moreover, Zucchi (1998) provides convincing arguments that stative predicates in the progressive can remain truly stative. 
b. ??Se está aburriendo y se va a aburrir.

SE is boring and SE go to bore

'He is bored, and he is going to get bored.'

c. ??Se está enfriando y se va a enfriar.

SE is cooling and SE go to cool

'It is cooling, and it is going to cool.'

Second, Kearns observes that the preliminary circumstance progressive is incompatible with durative adverbials, while the typical progressive is not. This contrast is illustrated in (37a-b) with prototypical process and achievement predicates. In $(37 \mathrm{c}-\mathrm{d})$ we see that the progressive forms of aburrirse and enfriarse behave like typical progressives. In (37e), the progressive with enfadarse is not unacceptable, but it has only an iterative reading; ${ }^{18}$ in other words, the sentence cannot be used to make a claim about the duration of the preliminary circumstance which gives rise to the anger, in exactly the same way that (37b) cannot make a claim about the duration of the preliminary circumstance which gives rise to the reaching of the summit.

a. Estuvo andando durante un rato. was walking during a while 'She was walking for a while.'

b. ??Estuvo alcanzando la cima durante un rato. was reaching the summit during a while 'He was reaching the summit for a while.'

c. Se estuvo aburriendo durante un rato.

SE was boring during a while

'She was (continuously) bored for a while.'

d. Se estuvo evaporando durante un rato.

SE was evaporating during a while

'It was (continuously) evaporating for awhile.'

e. Se estuvo enfadando durante un rato.

SE was angering during a while

'He was (repeatedly) getting angry for a while.'

Finally, following an observation by Mittwoch, Kearns points out that the progressive form of verbs that take only the preliminary circumstance progressive, unlike that of verbs allowing the typical progressive, is unacceptable with certain aspectual predicates such as continue (except on an irrelevant iterative reading). This contrast is shown in (38), with the Spanish equivalent of continue, seguir.

a. Si sigue aburriéndose, tendremos un problema.

If continues boring-SE, will have a problem

'If she continues being bored, we will have a problem.'

\footnotetext{
${ }^{18}$ Presumably this iterative reading is not available in (37b) for the pragmatic reason that one is not likely to repeat reaching a summit within a short period of time in the same way that one can repeat getting angry.
} 
b. Si sigue abriéndose, tendremos un problema.

If continues open-SE, will have a problem

'If it continues opening (continuously), we will have a problem.'

c. Si sigue enfadándose, tendremos un problema.

If continues angering-SE, will have a problem

'If he continues getting angry (repeatedly), we will have a problem.'

Kearns does not provide an explicit semantics for the preliminary circumstance progressive or an explanation for the contrasts in (36)-(38), and it is beyond the scope of this paper for us to do so here. What is important is that 1) the progressive with enfadarse verbs is decidedly different from that with aburrirse and enfriarse verbs, and 2) this difference is explainable under the assumption that enfadarse verbs, like other punctual verbs, have temporal properties that make them incompatible with the typical progressive, while aburrirse and enfriarse verbs are not incompatible with the progressive in this way. Moreover, we have already observed that progressive sentences containing aburrirse verbs (such as (8)) entail the corresponding sentences in the perfect, providing still further support that these verbs are atelic.

\subsection{Interpretation with reference time adverbials}

We now turn to a final set of data necessary for the characterization of SRPVs: evidence that they are inchoative. As will be made explicit in the following section, we consider a predicate inchoative if its reference necessarily includes the onset of some eventuality. We allow in principle for two subcases: the predicate may refer only to that onset, as will be the case for enfadarse verbs, or it may refer to the onset plus some portion of the eventuality in question the case, we argue, of aburrirse verbs.

The argument for the inchoativity of SRPVs is most relevantly applicable to the aburrirse verbs. On the semantics for achievement predicates that we adopt in the next section, all achievement predicates denote either the onset or the end of some eventuality (or, simultaneously, the end of one and the onset of another). If we exclude the possibility that enfadarse verbs denote the end of some eventuality on the basis of the evidence that they are not telic, it will follow by process of elimination that they must denote an onset. In contrast, so far we have seen evidence that aburrirse verbs are stative, but we have seen nothing to distinguish them from other stative predicates such as the semantically very similar estar + past participle form (e.g. estar aburrido 'to be bored').

The argument that aburrirse verbs are indeed what we might call inchoative statives comes from their interpretation with different kinds of reference time adverbials such as hace unos dias 'a few days ago' or mañana 'tomorrow' and quantificational adverbials such as siempre que 'whenever'. ${ }^{19}$ The logic of the argument is as follows. These adverbials provide a reference time interval for the interpretation of the clause they modify (Reichenbach 1947; see also Nerbonne 1984, Moens and Steedman 1988, inter alia). ${ }^{20}$ Stative predicates are usually understood in such a way that the interval over which the state in question holds (or,

\footnotetext{
${ }^{19}$ Quantificational adverbials are like reference time adverbials insofar as each instantiation of the temporal quantifier's restriction can serve as a reference time for an instance of the eventuality described in the nuclear scope of the quantifier.

${ }^{20}$ Though Reichenbach does not formalize his notion of reference time explicitly in terms of intervals, we will follow e.g. Partee (1984) and Moens and Steedman (1988) in assuming that the reference time is an interval. Klein's (1994) notion of topic time, similar to Reichenbach's reference time, is also conceived of as an interval.
} 
in Reichenbachian terms, the event time) can include this reference time interval. ${ }^{21}$ This is what we see in sentences such as (39a-b): (39a) is compatible with John being sick before and/or after any given occasion on which I need his help, while (39b) allows for the possibility that John's sickness began prior to yesterday and might continue into the present.

(39) a. Whenever I need his help, John is sick.

b. Yesterday, John was sick.

However, if a stative predicate were to include obligatory reference to the onset of the state described, we would expect that onset to occur within the time indicated by the reference time or quantificational adverbial. Examples like (40) show that, indeed, this is the case. (40a) establishes a (quantified) relation between situations of Ana having an exam and the onset of her being worried: All contextually relevant situations in which she has an exam are ones in which she begins to be worried (note the translation into English with inchoative get). In contrast, (40b) with the semantically similar but, we would argue, noninchoative estar + past participle form is infelicitous, as is the English translation provided below it. The infelicity is due to the fact that the sentence tries to establishes a generalization involving situations in which Ana has an exam and situations in which she may well already be worried, and such a generalization is pragmatically unlikely: It would be surprising that all cases of Ana having an exam would occur precisely when she was worried, perhaps for reasons entirely unrelated to the exam.

a. Siempre que Ana tiene un examen, se preocupa mucho.

whenever Ana has an exam, SE worries very much

'Whenever Ana has an exam, she gets very worried.'

b. ??Siempre que Ana tiene un examen, está muy preocupada. whenever Ana has an exam, is very worried ??'Whenever Ana has an exam, she is very worried.'

We can reproduce the same contrast with adverbials such as hace unos dias 'a few days ago' or mañana 'tomorrow.' When these adverbials are combined with an SRPV, the psychological state is inferred to begin within the time described by the adverbial, as indicated by the glosses in (41a) and (42a). However, when the adverbial combines with estar + past participle forms, no such inference is licensed: the students in (41b) and (42b) might well have been bored before entering class.

(41) a. Los estudiantes se aburrían en clase hace unos días.

the students SE bored in class ago some days

'The students got bored in class a few days ago.'

b. Los estudiantes estaban aburridos en clase hace unos días.

the students were bored in class ago some days

'The students were bored in class a few days ago.'

\footnotetext{
${ }^{21}$ With nonstative predicates the facts are more complicated because they depend on the form in which the predicate appears (e.g. progressive vs. nonprogressive) as well as the telicity of the predicate. See Cipria and Roberts (2000) and references cited there for additional discussion.
} 
(42) a. Mañana los estudiantes se aburrirán en clase. tomorrow the students SE will bore in class 'Tomorrow the students will get bored in class.'

b. Mañana los estudiantes estarán aburridos en clase. tomorrow the students will be bored in class 'Tomorrow the students will be bored in class.'

We thus see an important difference between the aburrirse verbs and other stative predicates, and a clear indicator that aburrirse verbs share the property of inchoativity with enfadarse verbs.

\subsection{Summary}

In this section we have shown on the basis of a variety of tests that SRPVs contrast with reflexive change of state predicates in lacking both telicity and dynamicity. The evidence provided supports the more specific conclusion that the aburrirse subclass is stative, while the enfadarse subclass is punctual but not stative. The results of these tests are summarized in Table 1, where a "+" value indicates acceptability with the indicated expression (on the indicated reading, where relevant), and a "-" value indicates unacceptability.

\begin{tabular}{|c|c|c|c|c|c|}
\hline & & & $\begin{array}{c}\text { Aburrirse } \\
\text { ('to get bored') }\end{array}$ & $\begin{array}{c}\text { Enfadarse } \\
\text { ('to get angry') }\end{array}$ & $\begin{array}{l}\text { Enfriarse } \\
\text { ('to cool') }\end{array}$ \\
\hline 1 & \multicolumn{2}{|c|}{$E n$ ('in') $\mathrm{x}$ time } & - & - & + \\
\hline 2 & \multicolumn{2}{|c|}{ Durante ('for') $\mathrm{x}$ time (noniterative reading) } & + & - & + \\
\hline 3 & \multicolumn{2}{|c|}{ Acabar/terminar 'finish' } & - & - & + \\
\hline 4 & \multicolumn{2}{|c|}{ Una vez absolutes } & - & - & + \\
\hline 5 & \multicolumn{2}{|c|}{ Slowly 'lentamente' } & - & - & + \\
\hline 6 & \multicolumn{2}{|c|}{ Parar 'stop' } & - & - & + \\
\hline 7 & \multicolumn{2}{|c|}{ Nonhabitual in present } & + & - & + \\
\hline \multirow{2}{*}{8} & \multirow{2}{*}{ Progressive } & Preliminary circumstance reading & - & + & - \\
\hline & & Ordinary reading entails perfect & + & Not applicable & - \\
\hline
\end{tabular}

Table 1: Summary of results for telicity and dynamicity diagnostics

In addition, we have argued that aburrirse verbs are inchoative on the basis of their interpretation with respect to reference time adverbials. Enfadarse verbs, we posit, are inchoative in virtue of being punctual but not telic.

It should be clear from this discussion that the relation between inchoativity, telicity, and change of state is not what the literature sometimes suggests. We are committed to there being inchoative verbs that are not telic. We must also make sense out of the notion of an inchoative stative. On the other hand, if we adopt the hypothesis that SRPVs are not true change of state predicates, a hypothesis that will prove to be quite natural on the semantics we adopt below, it does seem possible to maintain that all true change of state predicates can in principle be telic. 


\section{Analysis}

Our analysis makes use of the ontology for eventualities proposed in Piñon (1997). As mentioned in section 2.2, Piñón assigns to this ontology (among other things which will not be relevant here) two fundamentally different sorts of entities: happenings, which include events, states, and processes; and boundary happenings, which are the boundaries - i.e., onsets or endings - of happenings. Boundary happenings are special (and differ from ordinary happenings) in being truly instantaneous. This distinction can be visualized intuitively as in (43) (taken from Piñón 1997, example (11)), where $\mathbf{z}$ is a happening, $\mathbf{y}$ is the right boundary of $\mathbf{z}$, and $\mathbf{x}$ is the body of $\mathbf{z}$ (that is, $\mathbf{z}$ minus its left and right boundaries).

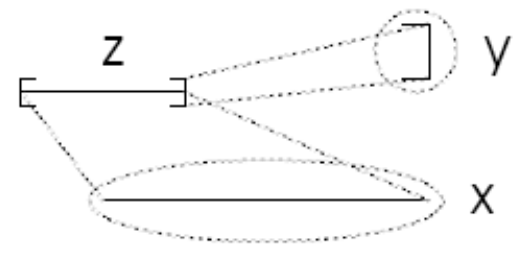

Note that in Piñón's system, $\mathbf{z}$ and $\mathbf{x}$ have the same temporal extension (or temporal trace); the presence of $\mathbf{y}$ adds nothing to the length interval that corresponds to $\mathbf{z}$. Although $\mathbf{y}$ is also assigned a corresponding temporal trace, this trace is a point rather than anterval, and an ontological distinction is maintained between intervals and points which parallels the one between happenings and boundary happenings. ${ }^{22}$

Piñón's proposal builds on the intuition (found in e.g. Vendler 1967, Mourelatos 1978, Freed 1979, and Mittwoch 1991) that some, if not all, of those predicates that are commonly labeled as achievement predicates denote events that lack any meaningful duration in time; precisely these predicates will denote boundary happenings, and Piñon reserves the term achievement just for them (e.g. begin or win). In contrast, his analysis of change of state predicates associates them with nontrivial temporal intervals; therefore, in his view, change of state predicates do not denote boundary happenings and therefore do not fall into the class of achievement predicates. This is crucial to our analysis, as we have already pointed out various contrasts between enfadarse verbs and so-called degree achievement verbs; as might be expected, we propose that enfadarse verbs are achievement predicates in Piñón's sense that is, they denote a special type of boundary happening - while verbs similar to enfriarse will denote a particular kind of regular happening.

Piñon argues that the logic of achievements is the logic of beginnings and endings. Since we are interested in characterizing the inchoativity of SRPVs, something like what he proposes will suit our purposes. Piñón defines beginnings as follows: They are boundary happenings of some particular type of eventuality, with the condition that this eventuality is not immediately preceded by another eventuality of exactly the same sort, as indicated in (44). ${ }^{23}$ Beg(inning) is a 3-place relation between a left boundary happening $e$, a happening $e^{\prime}$ that it is the boundary of, and the description $P$ of that happening. The final clause of the definition guarantees that $e^{\prime}$ is not immediately preceded («) by any other happening $e^{\prime \prime}$ that could form part of a larger happening with $e^{\prime}$ and which would also be describable as $P$; this larger happening is represented as the sum of $e^{\prime \prime}$ and $e^{\prime}\left(e^{\prime \prime} \oplus e^{\prime}\right)$.

\footnotetext{
${ }^{22}$ We cannot do full justice to Piñón's theory here; we provide just those definitions which are absolutely essential for understanding our proposal. The reader is referred to Piñón (1997) for additional details; in particular, he provides explicit definitions for the notions of left and right boundary.

${ }^{23}$ Our notation differs in inessential details from Piñón's, and in some cases the formulas are slightly simplified for ease of exposition.
} 


$$
\begin{aligned}
& \text { Beg: }=\lambda e \lambda e^{\prime} \lambda P\left[\text { Boundary-Happening }(e) \wedge \operatorname{Eventuality}\left(e^{\prime}\right)\right. \\
& \left.\wedge \text { Left-Boundary }\left(e, e^{\prime}\right) \wedge P\left(e^{\prime}\right) \wedge \neg \exists e^{\prime \prime}\left[e^{\prime \prime} \ll e^{\prime} \wedge P\left(e^{\prime \prime} \oplus e^{\prime}\right)\right]\right]
\end{aligned}
$$

We will define as inchoative any predicate which describes an eventuality which necessarily is or includes the beginning of some happening.

Boundary happenings which are endings are defined in an analogous fashion, as in (45).

$$
\begin{aligned}
& \text { End : }=\lambda e \lambda e^{\prime} \lambda P\left[\text { Boundary-Happening }(e) \wedge \text { Eventuality }\left(e^{\prime}\right)\right. \\
& \left.\wedge \text { Right-Boundary }\left(e, e^{\prime}\right) \wedge P\left(e^{\prime}\right) \wedge \neg \exists e^{\prime \prime}\left[e^{\prime} \ll e^{\prime \prime} \wedge P\left(e^{\prime} \oplus e^{\prime \prime}\right)\right]\right]
\end{aligned}
$$

As suggested in section 2.2, although Piñón does not discuss telicity, we might tentatively identify telic predicates with those that necessarily make reference to the ending of some happening, although an additional condition must be met in order for a predicate to count as telic, and in particular to distinguish what we might call "finishings" or "natural" endings from other kinds of endings which we might call "stoppings", such as the interruption of an activity or state (see also (52) below). Specifically, we tentatively propose that telic predicates must specify not only that there is no larger happening $\left(e^{\prime} \oplus e^{\prime \prime}\right)$ describable by the predicate in question but also that no such happening can exist. That is, we might define telic endings as the subtype of ending in (46):

(46) TelicEnd $:=\lambda e \lambda e^{\prime} \lambda P\left[\operatorname{Boundary}-H a p p e n i n g(e) \wedge \operatorname{Eventuality}\left(e^{\prime}\right)\right.$

$\left.\wedge \operatorname{Right-Boundary}\left(e, e^{\prime}\right) \wedge P\left(e^{\prime}\right) \wedge \neg \diamond \exists e^{\prime \prime}\left[e^{\prime} \ll e^{\prime \prime} \wedge P\left(e^{\prime} \oplus e^{\prime \prime}\right)\right]\right]$

Atelic predicates could be defined as those for which no such right boundary happening can be justifiably argued to exist.

Finally, note also that while nothing prevents a predicate from simultaneously denoting the end of one happening and the beginning of another (e.g. to be born might denote the end of a process of being born and the beginning of a state of being legally alive), it is possible for a predicate to denote the beginning of one eventuality without denoting the end of another, and vice versa. This is the key to understanding the semantics of SRPVs: The boundary happenings in their denotations are specified to be beginnings, but nothing is said about what they might be (ordinary or telic) endings of, and in this sense the verbs are inchoative without being telic. ${ }^{24}$

With the Beg(inning) relation in hand, we can now provide a semantics for the two classes of SRPVs. An achievement SRPV like enfadarse, once saturated by its experiencer argument, will denote the description of the beginning of the corresponding psychological state, as illustrated in (47), where in this case the state in question is represented by the predicate angry.

$$
\text { enfadarse: } \lambda x \lambda e \exists e^{\prime}\left[\mathbf{B e g}\left(e, e^{\prime}, \lambda e^{\prime \prime}\left[\operatorname{angry}\left(e^{\prime \prime}, x\right)\right]\right)\right]
$$

The semantics for a verb like aburrirse will be slightly different: its denotation, once the verb is saturated by an experiencer argument, will be the description of a state including, crucially,

\footnotetext{
${ }^{24}$ A stronger alternative would be to further specify in the denotation of SRPVs that there is no happening that they are the telic ending of. It is not clear to us at this point whether or not this stronger alternative would be preferable to the weaker one we will propose in the text.
} 
the beginning of that state, represented here as the sum of the boundary happening $e^{\prime}$ and the (state) happening $e^{\prime \prime}$.

$$
\text { aburrirse: } \lambda x \lambda e \exists e^{\prime}, e^{\prime \prime}\left[\operatorname{Beg}\left(e^{\prime}, e^{\prime \prime}, \lambda e^{\prime \prime \prime}\left[\operatorname{bored}\left(e^{\prime \prime \prime}, x\right)\right]\right) \wedge e=\left(e^{\prime \prime} \oplus e^{\prime}\right)\right]
$$

A crucial question we need to address is what kind of object this sum is. Specifically, 1) does it count as a state despite the presence of the initial boundary? and 2) is it homogeneous, or does the presence of the initial boundary render it nonhomogeneous?

Although Piñón does not treat cases exactly like the one in (48), he sets up the ontological distinction between boundary happenings and happenings in such a way that, while the sum of two happenings can be another happening, the sum of a boundary happening and a happening will be not a happening but rather a more general type of object that he terms an eventuality. It is also worth noting that it is a theorem of his system that all happenings have boundary happenings as parts. Both of these facts as well as other comments in his paper thus suggest that boundary happenings do not have an effect on the basic properties of the happenings that they are boundaries of, and we will therefore take the position that (48) does describe a state and has the homogeneity properties of a state despite the fact that it makes explicit reference to the state's initial boundary.

We now sketch briefly how this proposal can account for the facts presented in section 3. In order to do so we will have to make a number of working assumptions about the interpretation of tense and various types of temporal and aspectual expressions. These assumptions are not intended to necessarily represent the best analyses of the expressions in question; however, in all cases we have tried to make assumptions which are neither particularly controversial nor crucial to accounting for the facts.

First, consider the durante and en adverbials discussed in 3.1. Let us assume for the sake of illustration that such adverbials denote properties of eventuality descriptions, specifying some aspect of the duration of the eventuality in question. For instance, we could represent durante un rato 'for a while' as in (49), where awhile indicates a vague, contextually determined, and by default small interval of time (which is what un rato is):

\section{durante un rato: $\lambda P \lambda e[P(e) \wedge$ awhile $(\tau(e))]$}

In Piñón's semantics, happenings are associated with time intervals via a temporal trace function $\tau$. Thus, ignoring tense, we could represent the final interpretation of (50a) straightforwardly as in (50b), where existential closure binds the main event variable in the representation:

a. Marta se aburrió durante un rato.

Marta SE bored during a while

'Marta was bored for a while.'

$$
\text { b. } \exists e\left[\exists e^{\prime}, e^{\prime \prime}\left[\operatorname{Beg}\left(e^{\prime}, e^{\prime \prime}, \lambda e^{\prime \prime \prime}\left[\operatorname{bored}\left(e^{\prime \prime \prime}, \mathbf{m}\right)\right]\right) \wedge e=\left(e^{\prime \prime} \oplus e^{\prime}\right)\right] \wedge \operatorname{awhile}(\tau(e))\right]
$$

(50b) will be true as long as the temporal trace of the state, including its beginning, is at least as long as un rato requires. In contrast, this semantics for durante adverbials will have no way of combining meaningfully with enfadarse verbs. The temporal trace of the latter is a point in time, not an interval, and as mentioned in footnote 4 , points are ontologically distinct from intervals in this semantics. As a result, a property of intervals such as awhile will not be able to modify the temporal trace of an enfadarse verb, because the latter is not of the right sort. 
The semantics of en adverbials can be treated in terms of a similar sort of modification. The difference is that such adverbials will be restricted to modifying descriptions of events with telic endings.

en una hora: $\lambda P \lambda e[P(e) \wedge \tau(e) \leq 1 \mathrm{hr}]$, where $\exists e^{\prime}\left[\operatorname{TelicEnd}\left(e, e^{\prime}, P\right)\right]$

The adverbial in (51), like that in (49), will not apply to enfadarse verbs because boundary happenings lack the right sort of temporal trace. ${ }^{25}$ However, it will not combine with aburrirse verbs, either, because no telic right boundary is defined for those verbs.

The incompatibility of SRPVs with the two types of verbs of stopping that were discussed, namely acabar/terminar in section 3.2 and parar in section 3.5, is intuitively due to the lexically restrictions these verbs impose on their complements. Acabar and terminar select for telic eventualities, and parar, for dynamic ones. Such conditions can be added on top of the basic semantics for the intransitive use of verb stop (as in The activity stopped) proposed by Piñón and repeated in (52). On this semantics, stop combines with the description of an eventuality $e^{\prime}$ and yields a description of a different eventuality $e$, namely the event of $e^{\prime \prime}$ s stopping:

$$
\text { stop: } \lambda P \lambda e\left[\exists e^{\prime}\left[\mathbf{E n d}\left(e, e^{\prime}, P\right)\right]\right]
$$

The semantics in (52) places no conditions on what kind of eventuality $e^{\prime}$ can be, but it is straightforward to specify that in the case of acabar/terminar, that it must be one that has a telic ending. This can be done by having acabar/terminar denote a description of precisely such a telic ending, as in (53).

$$
\text { acabar/terminar: } \lambda P \lambda e\left[\exists e^{\prime}\left[\operatorname{TelicEnd}\left(e, e^{\prime}, P\right)\right]\right]
$$

If there is no way to satisfy TelicEnd for a given predicate $P$, then $P$ will not combine with acabar/terminar. This is what we would argue happens in the case of SRPVs.

Piñón's logic as presented in his 1997 paper does not make any distinction between states and other sorts of happenings, but he suggests that a basic sortal distinction could be built into the domain of happenings. If this were done, parar could be given a semantics identical to that in (52) but with the added specification that $e^{\prime}$ not be a state. This would block parar from combining with aburrirse verbs. In contrast, enfadarse verbs will be blocked because they denote boundary happenings: since the complement to End (represented as $P$ in (52)) must be a description of a happening and not of a boundary happening, enfadarse verbs will not be an appropriate sort of complement to parar.

Though a fully-argued account of the semantics of the una vez construction discussed in section 3.3 would take us beyond the scope of this paper, we can provide a brief sketch of how we might capture its failure to combine with SRPVs. Intuitively, the una vez construction, illustrated again in (54a), uses the telic end of an event to establish the earliest possible moment for the beginning of the eventuality described in the main clause to which the una vez construction is attached, as could be represented in $(54 \mathrm{~b}){ }^{26}$ If we assume that

\footnotetext{
${ }^{25}$ Obviously some account will be necessary for uses of such adverbials with achievement predicates on which they describe an interval prior to the occurrence of the eventuality in question, as in The plane arrived in one hour, just as something must be said about the semantic of the preliminary circumstance progressive. See e.g. Dowty (1979) and Nerbonne (1984) for two different early proposals.

${ }^{26}$ Two comments are in order: First, a full treatment of this construction, which appears only to have the syntax of a sentence-level modifier (in contrast, arguably, to durante and en adverbials), would require introducing tense and time into the clausal representations. For simplicity and because it is not really crucial to making clear
} 
both the participial phrase and the main clause that una vez combines with are not yet saturated by existential closure, the derivation of (54a) appears in (54e) as a result of the combination of (54b-d).
a. Una vez evaporada el agua, se extrae la sal. one time evaporated the water, SE extract the salt
'Once the water has evaporated, the salt is extracted.'
b. una vez: $\lambda P \lambda Q \lambda e\left[1 e^{\prime} \exists e^{\prime \prime}\left[\right.\right.$ TelicEnd $\left.\left.\left(e^{\prime}, e^{\prime \prime}, P\right)\right]<1 e^{\prime \prime \prime}\left[\operatorname{Beg}\left(e^{\prime \prime \prime}, e, Q\right)\right]\right]$
c. evaporada el agua: $\lambda e[\operatorname{evaporate}(e, 1 x[\operatorname{water}(x)])]$
d. se extrae la sal: $\lambda e \exists x[\operatorname{extract}(e, x, \mathfrak{r} y[\operatorname{salt}(y)])]$
e. (54a): $\lambda e\left[1 e^{\prime} \exists e^{\prime \prime}\left[\operatorname{TelicEnd}\left(e^{\prime}, e^{\prime \prime}, \lambda e[\operatorname{evaporate}(e, \mathfrak{1}[\operatorname{water}(x)])]\right)\right]\right.$
$\left.<\mathfrak{l} e^{\prime \prime \prime}\left[\operatorname{Beg}\left(e^{\prime \prime \prime}, e, \lambda e \exists z[\operatorname{extract}(e, z, \mathfrak{l} y[\operatorname{salt}(y)])]\right)\right]\right]$

As in the case of acabar/terminar, this semantics will be sortally incompatible with SRPVs, since these do not have a right boundary which satisfies TelicEnd.

An analysis in terms of sort mismatch is also in order for the behavior of SRPVs with lentamente described in 3.4. Recall that a verb fails to combine with lentamente if it is not dynamic. States are by their nature nondynamic; thus, the semantics of aburrirse verbs will be incompatible with any dynamicity entailments. Enfadarse verbs, as descriptors of boundary happenings, will likewise be blocked because they also lack dynamicity entailments: Dynamicity, as characterized in section 2.3 , is a property only of eventualities that occupy some nontrivial temporal interval.

We now turn to the facts presented in sections 3.6 and 3.7, namely the ability of aburrirse verbs to receive a nonhabitual interpretation in the simple present tense and to appear felicitously in the (ordinary) progressive. Both of these facts should follow directly if aburrirse verbs are stative (recall that we are assuming that at least some stative predicates can in principle occur in ordinary progressives in Spanish and Catalan, thanks to their homogeneous reference). However, the details of the analysis are not entirely trivial because we have to account for the apparently failure of the boundary happening that forms part of the eventuality described by aburrirse verbs to interact with either the present tense or the progressive, even though it decidedly does interact with reference time adverbials, as we will see momentarily.

Consider first the simple present tense. We will assume a "referential" approach to tense morphology on which the present tense introduces a freely-interpreted variable over times, where "time" for our purposes will constitute a supersort of points and intervals and include sums of points and intervals. Verbal predicates, once their other arguments are properly saturated, are then ascribed to these times to form propositions:

PRES $_{t}: g(t)$, where $g(t)$ is identical with the time of speech.

Up to now we have treated clauses as properties of events, which are turned into propositions via e.g. existential closure over the event variable. If we are going to combine $\mathbf{P R E S}_{t}$ with a clause, we will therefore need to convert the clause into a property of times that can be applied to the time the tense introduces. One way to do this, following e.g. Klein (1994), Kratzer (1998), and Katz (2003), is to appeal to aspectual operators to convert eventuality predicates into predicates of times. Katz proposes two operators: PROGRESSIVE and

how telicity interacts with una vez sentences, we will not do this here, though see below. Second, (54) would no doubt have to be strengthened with some sort of condition that guarantees a certain temporal and/or causal proximity between the occurrence of the two events in question. 
PERFECTIVE, shown in (56), where $\subset$ indicates temporal inclusion $\left(t \subset t^{\prime}\right.$ iff $t$ is properly included in $t^{\prime}$ ).
a. PROGRESSIVE: $\lambda P \lambda t \exists e[P(e) \wedge t \subset \tau(e)]$
b. PERFECTIVE: $\lambda P \lambda t \exists e[P(e) \wedge \tau(e) \subset t]$

Katz proposes (56a) as the semantics for English progressive morphology. We could therefore try to apply it to the representation for (57a) based on aburrirse in (48) to yield (57b), and apply the result to $\mathbf{P R E S}_{t}$ as in (57c). If we assume that $g(t)=t_{i}$ (identified as the utterance time in the case of the present tense) the final output is as in (57d):
a. Marta se está aburriendo.
Marta SE is boring
'Marta is bored.'
b. $\lambda t \exists e\left[\exists e^{\prime}, e^{\prime \prime}\left[\operatorname{Beg}\left(e^{\prime}, e^{\prime \prime}, \lambda e^{\prime \prime \prime}\left[\operatorname{bored}\left(e^{\prime \prime \prime}, \mathbf{m}\right)\right]\right) \wedge e=\left(e^{\prime \prime} \oplus e^{\prime}\right)\right] \wedge t \subset \tau(e)\right]$
c. $\lambda t \exists e\left[\exists e^{\prime}, e^{\prime \prime}\left[\operatorname{Beg}\left(e^{\prime}, e^{\prime \prime}, \lambda e^{\prime \prime \prime}\left[\operatorname{bored}\left(e^{\prime \prime \prime}, \mathbf{m}\right)\right]\right) \wedge e=\left(e^{\prime \prime} \oplus e^{\prime}\right)\right] \wedge t \subset \tau(e)\right]\left(\mathbf{P R E S}_{t}\right)$
d. $\exists e\left[\exists e^{\prime}, e^{\prime \prime}\left[\operatorname{Beg}\left(e^{\prime}, e^{\prime \prime}, \lambda e^{\prime \prime \prime}\left[\operatorname{bored}\left(e^{\prime \prime \prime}, \mathbf{m}\right)\right]\right) \wedge e=\left(e^{\prime \prime} \oplus e^{\prime}\right)\right] \wedge t_{i} \subset \tau(e)\right]$

For simple present tense we will have to assume a third aspectual operator, since the simple present and present progressive are not exactly synonymous. ${ }^{27}$ Since it has been argued that the eventuality descriptions in the simple present must hold exactly at the utterance time, we could use the following, which we dub "SIMPLE":

SIMPLE: $\lambda P \lambda t \exists e[P(e) \wedge t=\tau(e)]$

Applied to (59a) and following a derivation analogous to that in (57), we would derive the representation in $(59 \mathrm{~b})$ :
a. Marta se aburre.
Marta SE bore
'Marta is bored.'
b. $\exists e\left[\exists e^{\prime}, e^{\prime \prime}\left[\operatorname{Beg}\left(e^{\prime}, e^{\prime \prime}, \lambda e^{\prime \prime \prime}\left[\operatorname{bored}\left(e^{\prime \prime \prime}, \mathbf{m}\right)\right]\right) \wedge e=\left(e^{\prime \prime} \oplus e^{\prime}\right)\right] \wedge t_{i}=\tau(e)\right]$

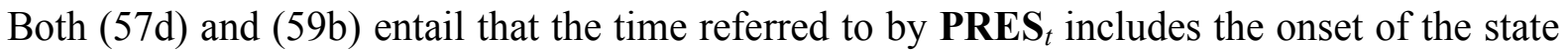
in question, rather than the simple existence of the state, while nothing in the semantics entails that the boredom must finish at the end of utterance time - only that a state of boredom holds within the utterance time. This latter aspect of the semantics is correct - it will be satisfied by any subpart of the state that includes the onset. However, the entailment that the onset be within the utterance time might seem more controversial: is it not too strong for (57a) and (59a) to require that the state begin at most at the beginning of the time of utterance, as opposed to at some time prior time?

We think not. It is arguably the case that speakers use sentences like (57a) when they are realizing for the first time that the state in question exists. It would be quite odd to utter

\footnotetext{
${ }^{27}$ Katz (2003) instead argues that stative predicates denote properties of times directly, rather than properties of events. Part of his reason for doing this is to account for the failure of stative predicates to occur in the progressive. We could follow his analysis by assigning stative predicates denotations like (57b), but then we would have to posit either ambiguity or coercion of some sort in order to account for the appearance of stative predicates in the progressive. Deciding which of these options is preferable is orthogonal to the point being made in this section, and obviously we cannot go into important questions here such as how to account for the restrictions on the interpretations of nonstative predicates in the simple present.
} 
such a sentence just after asserting via an estar + past participle form that the state in question already exists:

$$
\begin{aligned}
& \text { ??Estoy aburrido y me aburro. } \\
& \text { am bored and SE bore }
\end{aligned}
$$

The entailment that the onset of the state be within the utterance time is also arguably a good result for the progressive. Speakers report that (57a) can suggest that the boredom in question is not only present but increasing in degree. This would be a very natural thing to expect if we introduce reference to degree into the semantics of the adjective. Let's say that Marta is bored to degree $d$ prior to the utterance of (57a). (57a) would require that a distinct state of boredom begin at utterance time. One way for such a state to be distinct would be if the degree of boredom were no longer $d$ but rather $d+n .^{28}$ Note that, in contrast to (60), it is not a contradiction to utter (61):

(61) Estoy aburrido y me estoy aburriendo (todavía más).

am bored and SE am boring still more

'I'm bored and I'm getting even more bored.'

Finally, the semantics in (48) accounts directly for the inchoative interpretation of aburrirse verbs with reference time adverbials and the contrast with noninchoative estar + past participle forms discussed in section 3.8. Consider (42a), repeated in (62a), for example. We treat mañana as a modifier of descriptions of times, as in (62b) (where tomorrow gets $_{i}$ its value indexically), and combine it with a tenseless version of the main clause in SIMPLE aspect (shown in (62c)). The result will be (62d), which can then combine with future tense.
a. Mañana Marta se aburrirá en clase. tomorrow Marta SE will bore in class
'Tomorrow Marta will get bored in class.'
b. mañana: $\lambda P \lambda t\left[P(t) \wedge t \subseteq\right.$ tomorrow $\left._{i}\right]$
c. $\lambda t \exists e\left[\exists e^{\prime}, e^{\prime \prime}\left[\operatorname{Beg}\left(e^{\prime}, e^{\prime \prime}, \lambda e^{\prime \prime \prime}\left[\operatorname{bored}\left(e^{\prime \prime \prime}, \mathbf{m}\right)\right]\right) \wedge e=\left(e^{\prime \prime} \oplus e^{\prime}\right)\right] \wedge t=\tau(e)\right]$
d. $\lambda t \exists e\left[\exists e^{\prime}, e^{\prime \prime}\left[\operatorname{Beg}\left(e^{\prime}, e^{\prime \prime}, \lambda e^{\prime \prime \prime}\left[\operatorname{bored}\left(e^{\prime \prime \prime}, \mathbf{m}\right)\right]\right) \wedge e=\left(e^{\prime \prime} \oplus e^{\prime}\right)\right] \wedge t=\tau(e)\right.$
$\left.\wedge t \subseteq \operatorname{tomorrow}_{i}\right]$

(62d) directly entails that the beginning of the state of boredom will be included in the time determined by mañana - the inchoative interpretation. Contrast this with the noninchoative (63a), which will have the interpretation in (63b) (again, prior to combining with tense):
a. Mañana Marta estará aburrida en clase.
tomorrow Marta will be bored in class
'Tomorrow Marta will be bored in class.'
b. $\lambda t \exists e\left[\exists e\left[\operatorname{bored}(e, \mathbf{m}) \wedge t=\tau(e) \wedge t \subseteq \operatorname{tomorrow}_{i}\right]\right.$

(63b) will be true even if the state of boredom in question is included in a larger state that begins prior to the time determined by $\operatorname{tomorrow}_{i}$. Thus, the lack of a necessarily inchoative reading in (63a) follows directly.

\footnotetext{
${ }^{28}$ Note, interestingly, that the boredom in such a context could not be decreasing, i.e. the degree of boredom described in (57a) could not be $d-n$, since being bored to degree $d$ entails being bored to degree $d-n$ and thus the latter state would have held prior to utterance time.
} 
Having concluded this brief sketch of how the analysis can be made to account for the facts from section 3, we now consider previous analyses of Spanish se with special emphasis on SRPVs and connections to the analysis presented here.

\section{Other analyses of se}

Since this is the first formal semantic analysis that we are aware of specifically for SRPVs, a direct comparison with alternative analyses is not possible. However, we would like to offer some brief comments on the differences between the analysis proposed here and the most relevant previous analyses of se predicates in Spanish.

Various treatments of the morpheme se in Spanish have associated it explicitly with telicity, including Nishida (1994), Sanz (1995), Zagona (1996), Sanz and Laka (2002), and McCready and Nishida (2008). We do not question the possibility that in some cases se has the function of inducing telicity in a predicate that is not otherwise necessarily telic - this may well be the case for pairs such as comer/comerse 'eat'/'eat up'. However, it should be clear from the discussion above that se does not have a telicity-inducing effect in the case of SRPVs. Thus, while we will not take a position on the difficult question of whether se can be assigned a uniform interpretation/function across all of its uses, if one is to be found, it will not have to do with telicity.

Closer to our analysis are the proposals to be found in Demonte and Masullo (1999) and De Miguel and Fernández Lagunilla (2004). In a discussion whose focus is not verbs per se but rather secondary predication, Demonte and Masullo explicitly assume that all SRPVs (which they call verbos de afección) are stative. However, their claim differs from that proposed here on two points: 1) it does not say anything specific about the inchoativity of these verbs, and 2) it classifies not just aburrirse verbs but also enfadarse verbs as stative. The hypothesis that these verbs are stative is related to Demonte and Masullo's analysis of the so-called adverbial use of adjectives illustrated in (64), in which the adjective describes the manner in which Juan walked. ${ }^{29}$

(64) Juan caminó nervioso.

Juan walked nervous

'Juan walked in a nervous way.'

SRPVs do not accept this kind of modification, as shown in (65):
a. *Juan se asustó nervioso.
Juan SE frightened nervous
('Juan got frightened in a nervous way.')

\footnotetext{
${ }^{29}$ This use is slightly different from depictive modification, which is found in Spanish, as in English.

(i) Juan salió contento.

Juan left happy

'Juan left happy.' (i.e. Juan was happy when he left)

Depictive modifiers do not describe the manner in which main predicate eventuality takes place. Many Spanish sentences containing adjectival secondary predicates are ambiguous between the two readings. The reader is referred to Demonte and Masullo (1999) for more details; see also Dowty (1972), McNally (1994).
} 


\section{b. *Pedro se preocupó intranquilo. \\ Pedro SE worried restless \\ ('Pedro worried in a restless way.')}

Demonte and Masullo attribute this unacceptability to the hypothesis that adjectives can be used in this way only to modify dynamic predicates. If they are correct, the facts in (65) follow directly from the analysis proposed above, as we have argued that neither subclass of SRPVs is dynamic. Our analysis differs from Demonte and Masullo's only in attributing the lack of dynamicity of the enfadarse verbs to their punctual nature.

De Miguel and Fernández Lagunilla's (2004) discussion of these verbs is brief and falls within a general analysis of event structure inspired in Generative Lexicon theory (Pustejovsky 1995). They treat SRPVs as compound achievement predicates (what they term logros compuestos) consisting of a culmination followed by a state, as in (66), where L2 represents one of three types of achievements in their theory.

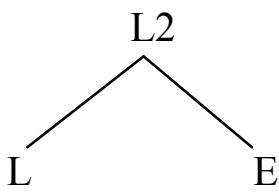

The presence of the culmination subevent $\mathrm{L}$ is clearly intended to account for the inchoativity of SRPVs; the presence of the state E indicates what kind of eventuality is initiated. Thus, this proposal greatly resembles the analysis of aburrirse verbs given in section 4; however, De Miguel and Fernández Lagunilla suggest that this same event structure should be also used for enfadarse verbs. It is also striking to observe that they claim, in response to Demonte and Masullo (1999) (and in contrast to the analysis defended here), that all of the verbs in question are dynamic. What the analysis in (66) and the discussion in De Miguel and Fernández Lagunilla (2004) underscore is the importance of providing an explicit semantics alongside such event structures. Without such a semantics it is difficult to determine how any predictions possibly made by (66) resemble or differ from those made by the analysis in section 4.

\section{Conclusion}

Our study of Spanish reflexive psychological verbs points to the need for distinguishing inchoativity from telicity and change of state: all SRPVs are inchoative, but they are not telic, nor do they refer directly to a change of state. The semantics we propose nonetheless allows us to maintain an ontological and aspectual distinction between the two subclasses of SRPVs: the enfadarse verbs are achievement predicates as defined in Piñón (1997), that is, they denote boundary happenings, while the aburrirse verbs denote states but also necessarily include reference to the left boundary of those states. The analysis has the further advantage of providing a way to capture the fact that not all achievement predicates are telic: only those which denote a right boundary happening are.

In addition to shedding light on the relationship between inchoativity and telicity, and more specifically on the often puzzling class of achievement predicates, the examination of SRPVs underscores the perhaps obvious but underappreciated fact that we can allude to changes by talking explicitly about the onset of the states produced by those changes. This should come as no surprise. As Smith (1991) observes, we can do the reverse: allude to states by talking explicitly about the events that produce them, 
"States can...be presented indirectly. This happens when a sentence lexically focuses a change of state. Such sentences allow the inference that the resultant state continues, unless there is information to the contrary. Non-statives introduce states indirectly, by directly presenting events that produce them. [e.g. Mary got angry.]" (Smith 1991:44)

Nonetheless, the fact that the atelicity of SRPVs has previously gone unappreciated points to the importance of investigating the Aktionsarten of the verbs in a given language through careful study of the semantic behavior of the classes of verbs within that language, rather than on the basis of intuitions about the general communicative effect of those verbs or about their translation equivalents in other languages.

\section{Acknowledgements}

This work has improved significantly thanks to comments from Edit Doron, Anita Mittwoch, Christopher Piñón and the anonymous reviewers for NLLT, as well as from audiences at Sinn und Bedeutung 9 and 10, the XXXIV Simposio de la Sociedad de Lingüística Española, SiNDay 2006 in Utrecht, the September 2006 meeting of the Semantiknetzwerk in Barcelona, and seminars at Universitat Pompeu Fabra and the Universitat Autònoma de Barcelona. We are also grateful for financial support from the Spanish Ministerio de Educación y Ciencia (MEC HUM2007-60599, HF2005-0177, and HA2005-0100), the Catalan Departament d'Universitats, Recerca i Societat de l'Informació (in the form of a Distinció de la Generalitat per a la Promoció de la Recerca Universitària, 2003-2007), and the French Agence Nationale de la Recherche (ANR 07-JCJC-0085-01).

\section{References}

Ackerman, Farrell, and John Moore. 2001. Proto-properties and grammatical encoding: A correspondence theory of argument selection. Stanford: CSLI.

Arad, Maya. 1998. Psych-notes. UCL Working Papers in Linguistics 10.

Belletti, Adrianna, and Luigi Rizzi. 1988. Psych-verbs and Theta Theory. Natural Language and Linguistic Theory 3:291-352.

Bennett, Michael, and Barbara Partee. 1972. Toward the logic of tense and aspect in English. Bloomington, IN: IULC.

Borik, Olga. 2006. Aspect and reference time. Oxford: Oxford University Press.

Cabré, Teresa, and Jaume Mateu. 1998. Estructura gramatical i normativa lingüística. A propòsit dels verbs psicològics en català. Quaderns. Revista de traducció 2:65-81.

De Miguel, Elena. 1999. El aspecto léxico. In Gramática descriptiva de la lengua española, eds. I. Bosque and V. Demonte, 2971-3060. Madrid: Espasa Calpe.

De Miguel, Elena, and Marina Fernández Lagunilla. 2000. El operador aspectual se. Revista Española de Lingüística, 30:13-43.

De Miguel, Elena, and Marina Fernández Lagunilla. 2004. Un enfoque subeventivo de la relación entre predicados secundarios y adverbios de manera. Revue Romane 39:24-44.

Demonte, Violeta, and Pascual J. Masullo. 1999. La predicación. Los complementos predicativos. In Gramática descriptiva de la lengua española, eds. I. Bosque and Violeta Demonte, 2461-2524. Madrid: Espasa Calpe.

Dölling, Johannes, Tatiana Heyde-Zybatow and Martin Shaefer (eds.). 2007. Event structures in linguistic form and interpretation. Berlin: Mouton de Gruyter. 
Dowty, D. 1972. Temporally restricted predicates. In Syntax and Semantics, Volume 1, ed. J. P. Kimball, 51-62. New York: Academic Press.

Dowty, David. 1979. Word meaning and Montague Grammar. Dordrecht: Reidel.

Dowty, David. 1991. Thematic proto-roles and argument selection. Language 67:547-619.

Filip, Hana. 1996. Psychological predicates and the syntax-semantics interface. In Conceptual structure, discourse and language, ed. A. Goldberg, 131-147. Stanford: CSLI.

Freed, Alice F. 1979. The semantics of English aspectual complementation. Dordrecht: Reidel.

Fontana, Josep M. 1991. Catalan and Spanish psych-verbs and the Universal Alignment Hypothesis. Paper presented at the Twenty First Linguistic Simposium on Romance Languages, Santa Barbara, CA.

Gavis, Wendy A. 1998. Stative verbs in the progressive aspect: A study of semantic, pragmatic, syntactic and discourse patterns. Ed.D. dissertation, Columbia University Teachers College.

Grimshaw, Jane. 1990. Argument structure. Cambridge, MA: MIT Press.

Hay, Jen, Christopher Kennedy, and Beth Levin. 1999. Scalar structure underlies telicity in degree achievements. In Proceedings of SALT 9, eds. T. Matthews and D. Strolovich, 127-144. Ithaca, NY: CLC Publications.

Hernanz, María Luisa. 1991. Spanish absolute constructions and aspect. Catalan Working Papers in Linguistics 1:75-128.

Hernanz, María Luisa, and Avel·lina Suñer. 1999. La predicación: La predicación no copulativa. Las construcciones absolutas. In Gramática descriptiva de la lengua española, eds. I. Bosque and V. Demonte, 2525-2560. Madrid: Espasa Calpe.

Katz, Graham. 2003. On the stativity of the English perfect. In Perfect explorations, eds. A. Alexiadou, M. Rathert and A. von Stechow, 205-234. Berlin: Mouton de Gruyter.

Kearns, Kate. 2003. Durative achievements and individual-level predicates on events. Linguistics and Philosophy 26:595-635.

Kempchinsky, Paula and Roumyana Slabakova. 2005. Aspectual Inquiries. Dordrecht: Springer.

Kennedy, Christopher, and Beth Levin. 2008. Measure of change: The adjectival core of degree achievements. In L. McNally and C. Kennedy (eds.), 156-182.

Klein, Wolfgang. 1994. Time in language. London: Routledge.

Kratzer, Angelika. 1998. More structural analogies between pronouns and tenses. In Proceedings of Semantics and Linguistic Theory VIII, eds. D. Strolovitch and A. Lawson, 92-110. Ithaca, NY: CLC Publications.

Krifka, Manfred. 1989. Nominal reference, temporal constitution and quantification in event semantics. In Semantics and contextual expression, eds. R. Bartsch, J. van Benthem, and P. von Emde Boas, 75-115. Dordrecht: Foris.

Marín, Rafael. 1996. Aspectual properties of Spanish absolute small clauses. Catalan Working Papers in Linguistics 5:183-202.

Marín, Rafael. 2004. Entre ser y estar. Madrid: Arco Libros.

McCready, Eric, and Chiyo Nishida. 2008. Reflexive intransitives in Spanish and event semantics. In J. Dölling, T. Heyde-Zybatow, and M. Schäfer (eds.), 223-244.

McNally, Louise. 1994. Adjunct predicates and the individual/stage distinction. In Proceedings of WCCFL 12, eds. E. Duncan, D. Farkas, and P. Spaelti, 561-576. Stanford, CA: CSLI Publications.

McNally, Louise, and Christopher Kennedy (eds.). 2008. Adjectives and adverbs: Syntax, semantics, and discourse. Oxford: Oxford University Press. 
Mendikoetxea, Amaya. 1999. Construcciones con se: Medias, pasivas e impersonales. In Gramática descriptiva de la lengua española, vol. 2, eds. I. Bosque and V. Demonte, 1631-1722. Madrid: Espasa Calpe.

Mittwoch, Anita. 1991. In defence of Vendler's achievements. In Perspectives on aspect and Aktionsart (Belgian Journal of Linguistics 6), eds. C. Vetters and W. Vandeweghe, 7185.

Moens, Marc, and Mark Steedman. 1988. Temporal ontology and temporal reference. Computational Linguistics 14:15-28.

Mourelatos, Alexander P. D. 1978. Events, processes, and states. Linguistics and Philosophy 2:415-434.

Nerbonne, John. 1984. German temporal semantics: Three-dimensional tense logic and GPSG fragment. Ph.D. dissertation, The Ohio State University. Published 1985 by Garland Press, New York.

Nishida, Chiyo. 1994. The Spanish reflexive clitic se as an aspectual class marker. Linguistics 32:425-58.

Parodi, Claudia, and Marta Luján. 2000. Aspect in Spanish psych verbs. In Hispanic Linguistics at the Turn of the Century, ed. H. Campos, 210-221. Somerville, MA: Cascadilla Press.

Parsons, Terence. 1990. Events in the semantics of English. Cambridge, MA: MIT Press.

Partee, Barbara H. 1984. Nominal and temporal anaphora. Linguistics and Philosophy 7:243286.

Pérez Jiménez, Isabel. 2007. Las cláusulas absolutas. Madrid: Visor.

Piñón, Christopher. 1997. Achievements in an event semantics. In Proceedings of Semantics and Linguistic Theory VII, eds. A. Lawson and E. Cho, 273-296. Ithaca, NY: CLC Publications. Extended unpublished version available at http://pinon.sdfeu.org/papers/pinon aes long.pdf.

Piñón, Christopher. 2008. Aspectual composition with degrees. In L. McNally and C. Kennedy (eds.), 183-219.

Pustejovsky, James. 1988. The geometry of events. In Studies in generative approaches to aspect (Lexicon project working papers, 24), ed. C. Tenny. Cambridge: MIT Press.

Pustejovsky, James. 1991. The syntax of event structure. Cognition, 21, 47-81.

Pustejovsky, James. 1995. The generative lexicon. Cambridge, MA: MIT Press.

Pylkkänen, Liina. 2000. On stativity and causation. In Events as grammatical objects: The converging perspectives of lexical semantics and syntax, ed. C. Tenny and J. Pustejovsky, 417-445. Stanford: CSLI.

Reichenbach, Hans. 1947. Elements of symbolic logic. London: Macmillan.

Roberts, Craige, and Alicia Cipria. 2000. Spanish imperfecto and preterito: Truth conditions and aktionsart effects in a situation semantics. Natural Language Semantics 8:297-347.

Ryle, Gilbert. 1949. The Concept of Mind. Harmondsworth: Peregrine Books.

Rothstein, Susan. 2008a. Telicity and Atomicity. In S. Rothstein (ed.), 43-78.

Rothstein, Susan (ed.) 2008b. Theoretical and crosslinguistic approaches to the semantics of aspect. Amsterdam: John Benjamins.

Sánchez López, Cristina (ed.) 2002. Las construcciones con se. Madrid: Visor.

Sanz, Montserrat. 1995. Telic clitics in Spanish. Ms., University of Rochester.

Sanz, Montserrat, and Itziar Laka. 2002. Oraciones transitivas con se: el modo de acción en la sintaxis. In C. Sánchez López (ed.).

Smith, Carlota. 1991. The parameter of aspect. Dordrecht: Kluwer.

Von Stechow, Arnim. 1996. The different readings of wieder 'again': A structural account. Journal of Semantics 13, 87-138.

Taylor, Barry. 1977. Tense and continuity. Linguistics and Philosophy 1:199-220. 
Tenny, Carol. 1994. Aspectual roles and the syntax-semantics interface. Dordrecht: Kluwer.

Treviño, Esthela. 1992. Subjects in Spanish causative constructions. In Romance languages and modern linguistic theory: Papers from the 20th Linguistic Symposium on Romance Languages, eds. P. Hirschbühler and K. Koerner, 309-324. Amsterdam/Philadelphia: John Benjamins.

Van Voorst, Jan. 1992. The aspectual semantics of psychological verbs, Linguistics and Philosophy 15:65-92.

Vendler, Zeno. 1967. Linguistics in philosophy. Ithaca, NY: Cornell University Press.

Verkuyl, Henk, Henriëtte de Swart, and Angeliek van Hout. 2005. Perspectives on Aspect. Dordrecht: Springer.

Zagona, Karen. 1996. Compositionality of aspect: Evidence from Spanish aspectual se. In Aspects of Romance linguistics: Selected papers from the Linguistic Symposium on Romance Languages 24, eds. C. Parodi, C. Quicoli, M. Saltarelli, and M. L. Zubizarreta, 475-488. Washington, D.C.: Georgetown University Press.

Zucchi, Alessandro. 1998. Aspect shift. In Events and Grammar, ed. S. Rothstein, 349-370. Dordrecht: Kluwer. 